ВойтунТ.В.,

Наиіональний технічний університет України «КПI»

\title{
ОСОБЛИВОСТІ ФОРМУВАННЯ СИСТЕМИ ЗАБЕЗПЕЧЕННЯ ІННОВАЦІЙНОЇ АДАПТИВНОСТІ ПІДПРИЕМСТВА
}

\author{
ОСОБЕННОСТИ ФОРМИРОВАНИЯ СИСТЕМЫ ОБЕСПЕЧЕНИЯ \\ ИННОВАЦИОННОЙ АДАПТИВНОСТИ ПРЕДПРИЯТИЯ
FONDATION'S FEAUTRES OF ENSURING SYSTEM OF INNOVATIVE ADAPTABILITY OF ENTERPRISE

\begin{abstract}
Стаття охоплюе теоретико-методичні аспекти формування системи забезпечення інноваційної адаптивності підприємства. У дослідженні розглянуто формування системи забезпечення здатності підприємства реагувати на зміни зовнішнього середовища та знижувати їх потениійний негативний ефект за допомогою інновачій. Запропоновано уточнення поняття «адаптивності» та «інноваційної адаптивності» підприємства, систематизовано види адаптаційних процесів на підприємстві, а також досліджено матрищю вибору інновачійно-адаптивної стратегії підприємства. Адже успішне функціонування підприємства у складному та динамічному середовищі тісно пов'язане з перерахованими поняттями та вимагає мобілізачіі зусиль підприємства для їх забезпечення. У даній статті розглядається авторське бачення механізму забезпечення ефективності інновачійної адаптивності підприємства та обтрунтовано його головні елементи. Наголомено на важливості такого принципу інновачійної адаптивності як узгодження адаптаційних дій із загальною стратегією підприємства, щзо є необхідною умовою забезпечення загальної ефективності системи інноваційної адаптивності підприємства.
\end{abstract}

Ключові слова: адаптивність, інноваційна адаптивність підприємства, система забезпечення інноваційної адаптивності підприємства.

Статья охватывает теоретико-методические аспекты формирования системь обеспечения инноваџионной адаптивности предприятия. В исследовании рассмотрено формирование системы обеспечения способности предприятия реагировать на изменения внешней среды и снижать их потенциальный негативный эффект с помощьью инноваций. Предложено уточнение понятия «адаптивности» $u$ «инноваџионной адаптивности» предприятия, систематизировань виды адаптащионных процессов на предприятии, а также исследовано матрищу выбора инновационно-адаптивной стратегии предприятия. Ведь успешное функиионирование предприятия в сложном и динамичной среде тесно связано с перечисленными понятиями и требует мобилизации усилий предприятия для их обеспечения. $B$ данной статье рассматривается авторское видение механизма обеспечения эффективности инновачионной адаптивности предприятия и обосновано его главные элементы. Подчеркнута важность такого принципа инновачионной адаптивности как согласование адаптационных действий $c$ общей стратегией предприятия, что является необходимым условием обеспечения общей эффективности системы инновационной адаптивности предприятия. 
Ключевые слова:адаптивность, инновационная адаптивность предприятия, система обеспечения инновационной адаптивности предприятия.

The article covers the theoretical and methodological aspects of innovation adaptability of enterprise. The article examined the formation of reference system to ensure the enterprise's ability to respond to changes in the environment and reduce their potential negative impact through innovation. Proposed clarification of the concept of "adaptability" and "innovative adaptability" of enterprise, systematized kinds of adaptive processes in the enterprise, and also investigated the matrix of innovation and adaptive enterprise strategy choice. After the successful operation of the enterprise in a complex and dynamic environment is closely linked with the above concepts and requires mobilization of the enterprise to provide them. This article discusses the author's vision of a mechanism to ensure the effectiveness of innovation and adaptability of enterprises justified its main elements. Highlighted this principle as an innovative adaptive coordination of adaptation actions on the overall strategy of the enterprise, which is a prerequisite for the overall efficiency of the enterprise innovation systemof adaptability.

Keywords:adaptability, innovation adaptability of enterprise, providing system of innovative adaptability of enterprise.

Вступ. Сучасний діловий світ характеризується прискореними темпами оновлення технологій, високим рівнем конкуренції у всіх сферах діяльності та жорсткими методами боротьби за лідерство. В таких умовах виживання та успіх будь-якого підприємства залежать від двох ключових факторів: інноваційності (як комплексної характеристики ступеня впровадження інновацій) та адаптивності (як здатності системи швидко та адекватно пристосовуватися до динамічних змін у середовищі функціонування). 3 таких позицій тематика представленої статті є досить актуальною та перспективною.

Слід відмітити, що проблемі забезпечення інноваційності та адаптивності сучасних підприємств присвячено велику кількість наукових досліджень. Серед них слід відмітити як праці класичного спрямування в теорії інноваційного менеджмент (В. Захарченко, Н. Корсікова, М. Меркулов, П. Микитюк, Й. Шумпертер)[1, 2, 6], так і дослідження за більш новітніми напрямками, зокрема стосовно проблематики інноваційної адаптивності підприємства (Л. Окопний, В. Прохорова, П. Свідерський, I. Новаківський) $[3,5]$. В зазначених дослідженнях приділяється чимало уваги інноваційному аспекту розвитку підприємства, проте, на наш погляд, недостатньо систематизовано сукупність концептуальних характеристик, що визначають систему забезпечення інноваційної адаптивності підприємства.

Постановка завдання. 3 огляду на зазначене, основною метою даного дослідження $є$ систематизація концептуальних положень стосовно інноваційної адаптивності та обгрунтування механізму забезпечення ефективності інноваційної адаптивності підприємства. 3 огляду на зазначену мету доцільно сформулювати наступні цілі:уточнення поняття «інноваційної адаптивності» підприємства; визначення складових механізму забезпечення інноваційної адаптивності; обгрунтування дієвості зазначеного механізму. 
Методологія.Теоретичною та методологічною основою $є$ роботи провідних вітчизняних і зарубіжних учених 3 інноваційного розвитку та адаптивного управління. У статті використано сукупність методів: системного аналізу - при визначенні теоретичних засад інноваційної адаптивності промислових підприємств; класифікаційно-аналітичний - при розробці понятійного апарату забезпечення інноваційної адаптивності; абстрактнологічний - при теоретичному узагальненні результатів дослідження та формулюванні висновків.

Результати дослідження. Для розв'язання поставленого завдання необхідно передусім з'ясувати сутність поняття адаптивність та інноваційна адаптивність. Як стверджують В. Ячменьова та 3. Османова, аналіз поняття «адаптивність» дає змогу виділити ключові слова, в межах яких воно розглядається [7]. Це - властивість, реакція, здатність, характеристика (табл. $1)$.

Таблиця 1

Аспекти сутності поняття «адаптивність»

\begin{tabular}{|c|c|}
\hline $\begin{array}{l}\text { Ключове } \\
\text { слово }\end{array}$ & Сутність поняття в межах ключового слова \\
\hline \multirow{2}{*}{ Властивість } & $\begin{array}{l}\text { системи, що визначає іiі здатність успішно пристосовуватися до умов } \\
\text { зовнішнього середовища, що змінюється }\end{array}$ \\
\hline & $\begin{array}{l}\text { що полягає в пристосуванні до внутрішньофірмових і макроекономічних } \\
\text { змін та в багатоаспектності, що виражаються в економічних стосунках }\end{array}$ \\
\hline Реакція & $\begin{array}{l}\text { на зміну чинників зовнішнього середовища за рахунок перебудови зв'язків } \\
\text { і стосунків між суб'єктами }\end{array}$ \\
\hline \multirow{3}{*}{ Здатність } & $\begin{array}{l}\text { пристосуватися до поточних змін навколишнього середовища, } \\
\text { перебудовувати свої елементи і взаємозв'язки між ними відповідно до } \\
\text { трансформації зовнішнього середовища і внутрішніх перетворень }\end{array}$ \\
\hline & $\begin{array}{l}\text { системи пристосовуватися до змін середовища, можна визначити, що в } \\
\text { сучасних умовах разом } 3 \text { конкурентоспроможністю вона є основою } \\
\text { економічної стійкості діяльності підприємства }\end{array}$ \\
\hline & $\begin{array}{l}\text { системи, організації або окремої людини пристосовуватися до різних умов } \\
\text { навколишнього середовища називають адаптивністю }\end{array}$ \\
\hline \multirow{2}{*}{$\begin{array}{l}\text { Характеристи } \\
\text { ка }\end{array}$} & $\begin{array}{l}\text { діяльності підприємства, здібність (властивість економічної системи) його } \\
\text { до самозбереження, пристосування, структурної перебудови, перетворення } \\
\text { в умовах нестабільності }\end{array}$ \\
\hline & $\begin{array}{l}\text { підприємства приростного типу, яка орієнтується на стабільність і повільні } \\
\text { зміни зовнішнього середовища і встигає в таких умовах реагувати на } \\
\text { виникаючі проблеми }\end{array}$ \\
\hline
\end{tabular}

Джерело: систематизовано автором на основі [7].

Таким чином, враховуючи багатоаспектність категорії «адаптивність» дамо авторське визначення цього терміну з позицій інноваційної організації, що говорить про подальше вивчення даної категорії в економіці.

Адаптивність - це здатність системи до швидкого та якісного пристосування до змін у внутрішньому та зовнішньому середовищі, яке сприяє іїі розвитку та підвищенню життєздатності. 
Виходячи $з$ такого розуміння адаптивності, пропонуємо розглядати інноваційну адаптивність як здатність системи аналізувати та відслідковувати зміни зовнішнього та внутрішнього середовища, та відповідним чином змінювати функціонування та структуру за допомогою інновацій, 3 метою збереження чи досягнення оптимального стану діяльності соціальноекономічної системи.

Як стверджують сучасні дослідники, існують випадки, коли адаптивний розвиток підприємств відбувається і без застосування інновацій. Але слід зважити на те, що підприємство не зможе успішно тривалий час дотримуватися виконання сформованих алгоритмів управління. Виходячи із цього адаптивний інноваційний розвиток - процес реалізації нововведень, які здатні пристосовувати підприємство до змін умов зовнішнього та внутрішнього середовища.

Унікальність структури й особливостей діяльності кожного підприємства дає можливість його менеджерам визначити загальні напрямки його адаптивного розвитку. 3 цієї точки зору адаптивне управління представляє собою комплекс організаційних та економічних компонентів, які забезпечують взаємо узгоджене функціонування всіх елементів системи реалізації нововведень, що дає змогу організації пристосовуватись до змін у зовнішньому i внутрішньому середовищі та успішно функціонувати в довгостроковому періоді [4].

Класифікацію можливих типів та видів адаптації інноваційного процесу на підприємстві систематизовано в табл. 2.

Таблиця 2

Класифікація видів адаптаційних процесів на підприємстві

\begin{tabular}{|c|c|c|}
\hline Ознака & $\begin{array}{c}\text { Вид } \\
\text { адаптації }\end{array}$ & Характерні особливості прояву в інноваційному процесі \\
\hline \multirow[b]{2}{*}{$\begin{array}{l}\text { За визна- } \\
\text { ченням } \\
\text { мети і } \\
\text { предмета } \\
\text { адаптації }\end{array}$} & $\begin{array}{c}\text { Приватна } \\
\text { (лінійна) } \\
\text { адаптація }\end{array}$ & $\begin{array}{l}\text { Розглядаються окремі чинники інноваційного розвитку (різні } \\
\text { інноваційні проекти) без їх взаємного узгодження, не потребує } \\
\text { докорінної перебудови існуючої схеми функціонування об'єкта }\end{array}$ \\
\hline & $\begin{array}{l}\text { Системна } \\
\text { (багато- } \\
\text { рівнева) } \\
\text { адаптація }\end{array}$ & $\begin{array}{l}\text { Розглядаються в сукупності всі чинники інноваційного } \\
\text { процесу на підприємстві, мають вплив на реалізацію } \\
\text { інноваційних процесів щодо об'єкта адаптації; вимагає зміни } \\
\text { існуючого підходу у вирішенні проблем, перевизначення } \\
\text { пріоритетів, встановлення } \\
\text { перепланування операцій }\end{array}$ \\
\hline \multirow{2}{*}{$\begin{array}{l}\text { За } \\
\text { ініціацією } \\
\text { та } \\
\text { об'єктив- } \\
\text { ними } \\
\text { ознаками }\end{array}$} & $\begin{array}{c}\text { Проблемна } \\
\text { адаптація }\end{array}$ & $\begin{array}{l}\text { «ніціатор» процесу адаптації - формалізована проблема на } \\
\text { шляху реалізації інновацій, отже, даний « подразник » } \\
\text { необхідно нейтралізувати, усунути або пистосуватися до } \\
\text { нього }\end{array}$ \\
\hline & $\begin{array}{l}\text { Комплексн } \\
\text { а адаптація }\end{array}$ & $\begin{array}{l}\text { «Ініціатор» процесу адаптації - сам об’єкт адаптації, коли } \\
\text { інновації не можуть розпочатись без попередньої підготовки, } \\
\text { тому рішення задачі адаптації лежить в області реінжинірингу }\end{array}$ \\
\hline
\end{tabular}




\begin{tabular}{|c|c|c|}
\hline & $\begin{array}{l}\text { Продуктов } \\
\text { а (резуль- } \\
\text { тативна) } \\
\text { адаптація }\end{array}$ & $\begin{array}{l}\text { «ніціатор» процесу адаптації - продукт виробництва, } \\
\text { пропонований на ринку самим підприємством, отже, необхідні } \\
\text { зміни в умовах внутрішнього середовища для отримання } \\
\text { очікуваного рівня результатів на виході системи }\end{array}$ \\
\hline \multirow{3}{*}{$\begin{array}{l}\text { За } \\
\text { підходом } \\
\text { до } \\
\text { вирішення } \\
\text { проблеми } \\
\text { адаптації }\end{array}$} & $\begin{array}{l}\text { Класична } \\
\text { адаптація }\end{array}$ & $\begin{array}{l}\text { Переважає вплив зовнішнього середовища на об'єкт адаптації } \\
\text { інновацій, тому відповідна реакція - традиційнийпідхід, } \\
\text { пов'язаний зі зміною його внутрішнього середовища }\end{array}$ \\
\hline & $\begin{aligned} \text { Прог } \\
\text { адаг }\end{aligned}$ & $\begin{array}{l}\text { Агресивна, вплив зовнішнього середовища } \\
\text { компенсовано за рахунок внутрішньої активності. }\end{array}$ \\
\hline & $\begin{array}{l}\text { Толерантна } \\
\text { адаптація }\end{array}$ & $\begin{array}{l}\text { Об’єкт, володіючи всім необхідним, може одночасно } \\
\text { виступати в ролі суб'єкта управління. Це дозволить йому } \\
\text { реалізувати підхід, що базується на передбаченні подій і } \\
\text { передбаченні майбутньої ситуації за час попередження та } \\
\text { прогнозуванні динаміки зміни ситуації, і стану об’єкта як } \\
\text { системи }\end{array}$ \\
\hline
\end{tabular}

Джерело: систематизовано автором на основі [1, 3]

У контексті дослідження інноваційного чинника на базі сучасних підприємств України, можна відзначити такі найбільш істотні цілі застосування інноваційної адаптивності, як збільшення асортименту продукції, збереження і розширення традиційних ринків збуту, поліпшення якості продукції, зростання виробничих потужностей, скорочення матеріальних i енергетичних витрат. Важливим фактором, що визначає домінування стратегії адаптивності серед інших на більшості підприємств України є кризовий стан як на макро-, так і на макрорівні.

Оскільки особливістю підприємства, що знаходяться у стані кризи, є жорстке ресурсне обмеження, доцільно запропонувати наступну матрицю для вибору інноваційно-адаптивної стратегії (рис. 1).

\begin{tabular}{|c|c|c|c|c|}
\hline \multirow{5}{*}{ 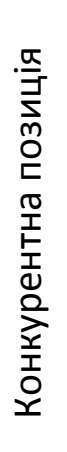 } & Сильна & $\begin{array}{l}\text { Інтенсивні НДДКР, } \\
\text { технологічне лідерство }\end{array}$ & $\begin{array}{l}\text { Стратегія } \\
\text { прямування } \\
\text { лідером }\end{array}$ & $\begin{array}{l}\text { Придбання іншої } \\
\text { фірми }\end{array}$ \\
\hline & Середня & $\begin{array}{l}\text { Пошук вигідних сфер } \\
\text { застосування технології }\end{array}$ & & Раціоналізація \\
\hline & Низька & $\begin{array}{l}\text { Організація ризикового } \\
\text { виробництва }\end{array}$ & Раціоналізація & $\begin{array}{l}\text { Ліквідація } \\
\text { бізнесу }\end{array}$ \\
\hline & & Сильна & Середня & Низька \\
\hline & & Технолог & нна позиція & \\
\hline
\end{tabular}

Рис. 1. Матриця для вибору інноваційно-адаптивної стратегї підприємства

Джерело: систематизовано автором на основі [1, 2]

Загалом, механізм забезпечення ефективності інноваційної адаптивності підприємства, на наш погляд, доцільно представити у двоконтурній формі 
відповідно до двох основних груп чинників адаптації - внутрішніх та зовнішніх (рис. 2).

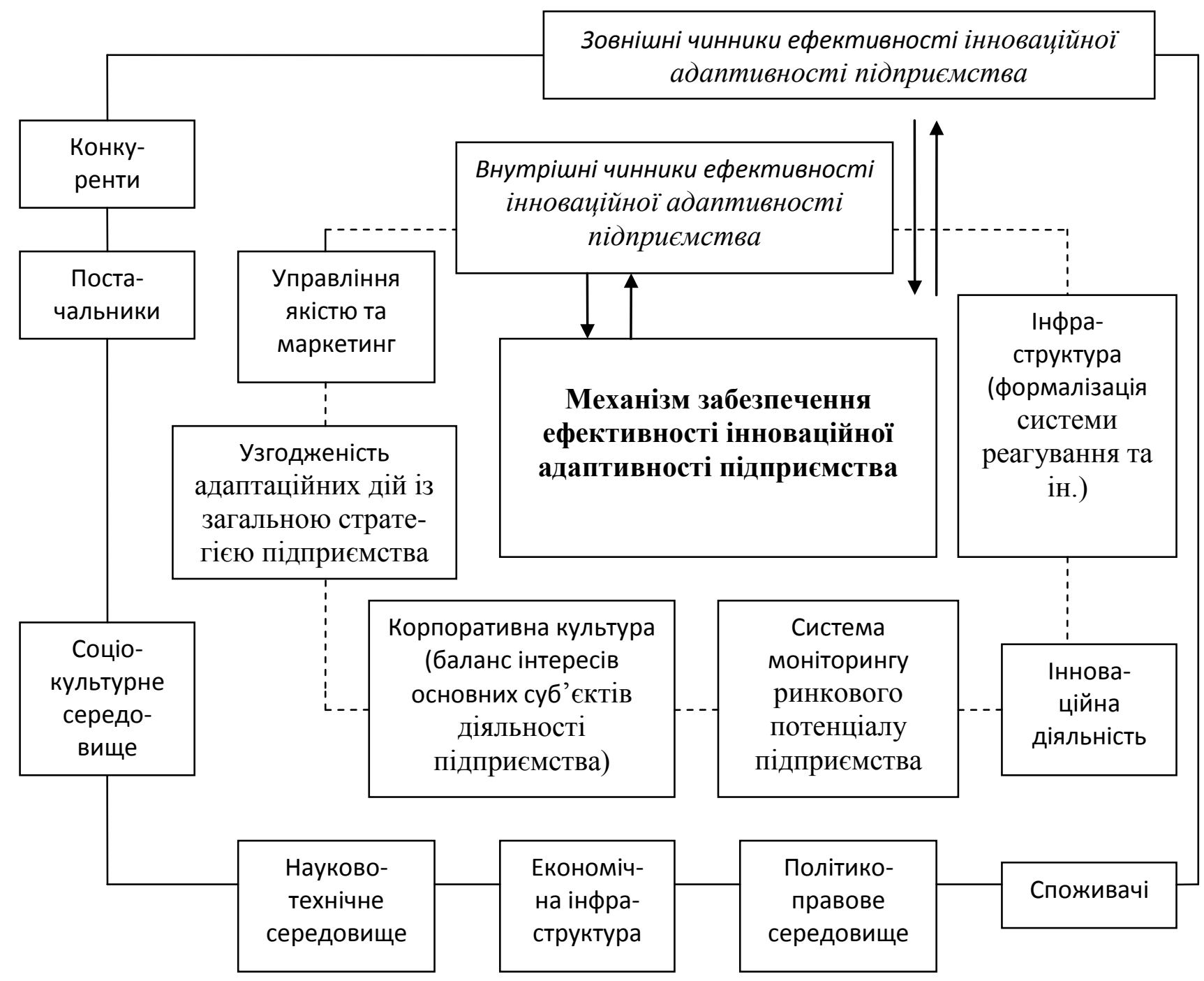

Рис. 2. Механізм забезпечення ефективності інноваційної адаптивності підприємства

Джерело: власні розробки автора

Зовнішні чинники ефективності інноваційної адаптивності - це, перш за все, споживачі, постачальники, конкуренти, соціокультурне, політико-правове та науково-технічне середовище, економічна інфраструктура (численні фінансово-кредитні, консалтингові та інші установи). Ступінь впливу кожного iз зазначених зовнішніх компонентів на узагальнюючу характеристику ефективності інноваційної адаптивності визначається, перш за все, специфікою конкретного підприємства. Наприклад, такий чинник, як наявність потужних конкурентів, відіграє важливу роль для переважної більшості промислових підприємств України. Однак для державних 
підприємств, особливо підприємств-монополістів цей чинник набуває другорядного значення в зв'язку істотною часткою держави у їх портфелі замовлень, більш важливим у цьому випадку виявляється такий чинник, як політико-правове середовище

У контексті зовнішнього аналізу ефективності інноваційної адаптивності підприємства слід зазначити важливість такого чинника, як науково-технічне середовище, що включає в себе провідні напрямки розвитку науки і техніки, продуктові та технологічні інновації, зокрема, появу нових ресурсозберігаючих технологій, постійне вдосконалення стандартів якості та підвищення вимог до вітчизняної продукції.

Зупинимось більш детально на внутрішніх чинниках ефективності інноваційної адаптивності підприємства, оскільки саме вони є визначальними 3 точки зору здатності підприємства як інституціонального комплексу до протистояння кризовим явищам та розвитку.

Чинник інфраструктури згідно авторського підходу передбачає формалізацію та істотне ресурсне забезпечення системи реагування на підприємстві (тобто створення спеціальної антикризової служби чи відділу моніторингу та реагування), а також інших важливих 3 точки зору адаптаційних можливостей інститутів. Це, зокрема, інститути інновацій та маркетингу, які в результаті авторських досліджень були визначені як домінантні з точки зору підвищення ефективності інноваційної адаптивності. Важливість зазначених інститутів обумовила їх окреме положення у схематичному поданні механізму забезпечення ефективності інноваційної адаптивності підприємства (рис. 2).

Також, слід відмітити важливість наявності системи моніторингу інноваційного розвитку підприємства як основоположний елемент механізму забезпечення ефективності інноваційної адаптивності.

В процесі авторського аналізу виявлено також важливість корпоративної культури як одного 3 елементів механізму забезпечення ефективності інноваційної адаптивності підприємства. Баланс інтересів основних суб'єктів діяльності підприємства представляється одним 3 найбільш перспективних напрямків підвищення рівня корпоративної культури.

У діяльності підприємства узгодженість адаптаційних дій із загальною стратегією підприємства $\epsilon$ необхідною умовою забезпечення ефективності системи інноваційної адаптивності. Дотримання цього принципу є виключно важливим на усіх етапах функціонування виробничої економічної системи та на всіх ㄲï рівнях (від пошуку постачальників сировини, виробництва до розробки інвестиційних проектів).

За умови відповідності складових та структури системи забезпечення ефективності інноваційної адаптивності підприємства вищенаведеним 
принципам досягатиметься вищий рівень стійкості та адаптивності підприємства, якості його управління.

Важливе значення у процесі переходу підприємства на концепцію інноваційної адаптивності відіграє готовність організаційної структури управління до передбачених обраною стратегією змін. Інноваційно орієнтована організаційна структура повинна задовольняти такі вимоги: підтримувати постійну генерацію нових ідей, сприяти проникненню нововведень у чинні організаційні правила і процедури, упроваджувати нові ідеї і перетворювати їх на частину щоденної оперативної роботи.

Можна виділити такі базові напрями інноваційних змін організаційної структури управління підприємством:

ідеологіі;

- концептуальні зміни стратегії розвитку, парадигми управління,

- структурні і функціональні зміни з урахуванням розвитку глобального інформаційного простору;

- дистанційне обслуговування через Інтернет, впровадження віртуальних управлінських технологій;

- реінжиніринг процесів (на основі переосмислення постулатів організації відповідної діяльності), подолання ключових обмежень [3].

Висновки. Отже, у даній статті подальшого розвитку набувають такі економічні категорії як інноваційна адаптивність та механізм забезпечення ефективності інноваційної адаптивності підприємства. Зрозуміло, що для досягнення оптимальних параметрів ефективності системи інноваційної адаптивності підприємства необхідно поєднувати адаптивні та інноваційні рішення на систематичній основі. В значній мірі реалізації цієї задачі сприятиме запропонований у статті механізм забезпечення ефективності інноваційної адаптивності підприємства, за допомогою вивчення якого, по суті, й набуває подальшого розвитку така економічна категорія як інноваційна адаптивність підприємства. Основною перевагою даного механізму є ефект синергії, який проявляється лише за комплексного врахування і активізації усіх елементів механізму. Тобто наукова новизна одержаних результатів полягає в удосконаленні теоретичних i концептуальних положень щодо формування механізму забезпечення ефективності інноваційної адаптивності підприємства, яке функціонує в ринкових умовах господарювання.

Практичне значення одержаних результатів полягає в тому, що запропонований механізм забезпечення ефективності інноваційної адаптивності підприємства становить комплексну методичну основу для обгрунтування управлінських рішень щодо забезпечення інноваційної адаптивності промислового підприємства. 
Перспективи подальших наукових досліджень полягають у емпіричних дослідженнях результативності запропонованого механізму стосовно практичної діяльності підприємств та організацій України.

\section{Література:}

1. Захарченко В. I Інноваційний менеджмент: теорія і практика в умовах трансформації економіки: [навч.посібник] / Захарченко В. І., Корсікова Н. М., Меркулов М.М. - К.: Центр учбової літератури, 2012. $-448 \mathrm{c}$.

2. Інноваційний менеджмент: [навч.посібник] / П.П. Микитюк. - Т.: Економічна думка, 2006. -295 c.

3. Новаківський I.I. Узгодження інноваційних та адаптивних змін організаційної системи управління підприємства [Електронний ресурс] / I.I Новаківський // Проблеми економіки та управління. - 2010. - № 684. - С. 140 . http://archive.nbuv.gov.ua/portal/natural/vnulp/Ekonomika/2010_684/29.pdf

4. Окопний Л.С. Адаптивний розвиток підприємств на основі інновацій [Електронний pecypc] / Л.С. Окопний // Міжнародна науково-практична Інтернет-конференція «Інноваційний шлях розвитку суспільства: проблеми, досягнення та перспективи». - Режим доступу:

http://sophus.at.ua/pub1/2013_05_30_31_kampodilsk/ekonomichnij_blok_doslidzhen/adaptivnij_r ozvitok_pidpriemstv_na_osnovi_innovacij/31-1-0-671

5. Прохорова В.В., Свідерській П.В. Адаптивний потенціал інноваційного розвитку підприємств в контексті економіки знань / В.В. Прохорова, П.В. Свідерській // Вісник економіки транспорту і промисловості. - 2011. - № 36. - С. 318-322

6. Шумпетер Й.А. Теорияэкономическогоразвития: Исследованиепредпринимательскойприбыли, капитала, кредита, процента и циклаконьюктуры / Й. А. Шумпетер - М., 1982. - 456 с.

7. Ячменьова В.М. Сутність понять «адаптація» та «адаптивність» [Електронний ресурс] / В.М. Ячменьова, 3.О. Османова // Проблеми економіки та управління. - 2010. - № 684. - С. 346.

Режим доступу:

http://archive.nbuv.gov.ua/portal/natural/vnulp/Ekonomika/2010_684/71.pdf 